\title{
Reverência a companheiros $e$ à atividade didática
}

Harley E. A. Bicas

Coordenar trabalhos de pessoas com ideais afinados por um propósito comum deixa de ser tarefa difícil e passa a atividade gratificante. Se as pessoas em questão possuem inteligência acima da média, ótima formação para o desempenho a ser executado e assumem as responsabilidades cabentes, então a coisa torna-se prazerosa. Tal tem sido minha participação junto ao Conselho Editorial dos A.B.O., uma equipe de alta competência, prévia e sabiamente selecionada por Rubens Belfort Júnior e cujo único mérito de minha parte é não tê-la desmontado mas, ao contrário, incentivado a que realize, em plenitude, suas potencialidades já antes demonstradas, mantido sua coesão e, em cada um, procurado desenvolver o espírito de grupo. Quando um tema começa a se mostrar problemático e a necessidade de mudanças aparece, logo surge uma idéia renovadora e eficaz tal como a de Goldchmit para eliminar a estagnação dos trabalhos na secretaria, aumentando-lhes o fluxo. Cristina Muccioli cuida da edição eletrônica, Samir pontifica sobre pendências éticas e jurídicas, Mauro Campos e Vital aguçam os aspectos metodológicos, mas todos se dedicam à causa dos A.B.O. sem regatear esforços. Um timaço. Claudete Moral cuida da retaguarda, o que é muito. Por aumento de suas incumbências, conta agora com Cláudia, para auxiliá-la. Paulo Imamura supervisiona as publicações, Hanna Rotschild revê o Inglês, Maria Elisa Rangel Braga e Edna Therezinha Rother cuidam da apresentação bibliográfica e dão solução a exigibilidades biblioteconômicas de formatação da revista. Henrique Kikuta provê fundos e a Diretoria do C.B.O. dá todo apoio logístico. Uma seleção para enfrentar qualquer campeonato. $\mathrm{O}$ que se pode querer mais? Como resultado de todo esse labor conjunto, conseguimos sair de uma pressão crônica em que vivíamos, preparando a impressão dos fascículos quase sem qualquer tempo para fazê-lo. Estamos chegando, até, a uma situação muito cômoda neste aspecto: um belo problema a resolver.

Assim é que, pela madrugada adentro de nossa mais recente reunião, acendeu-se um importante e pedagógico debate sobre os princípios e fins de um editorial, a propósito de duas cartas encaminhadas à Editoria Científica dos A.B.O. Os próprios temas tornaram-se objeto de análise, com interessantes ponderações. Ao final, restou-me a incumbência de discorrer sobre eles, logo eu, com opinião formada e, provavelmente, o menos imparcial. Tentarei equilibrar-me.

Sobre a cobrança de inscrições de conferencistas, em reuniões científicas, embora com toda e qualquer ponderação dialética, não me parece haver dúvidas de que se trata, no mínimo, de uma deselegância. Afinal, de um convidado que (presumivelmente) contribui com o evento trazendo-lhe sua essência, a informação; sendo para tal (presumivelmente) selecionado entre tantos e ainda (supostamente) permitindo que fundos sejam por meio dele arrecadados dos congressistas (inscrições e, às vezes, até mesmo, seus pagamentos extras à participação específica naquele curso), exigir-lhe o comprovante de pagamento a sua presença no recinto, fere o bom senso, pelo próprio desmerecimento intrínseco da atividade magisterial. O ideal seria, até, que esse professor tivesse, pagas, todas as suas despesas de transporte, estada e alimentação (como se faz ao convidado estrangeiro que, por ser estrangeiro, deve ser melhor que o brasileiro...) e, ademais, recebesse um "pró-labore" (como exigem conferencistas de outras áreas, que se dão valor profissional). Assim, os "curricula" acadêmicos poderiam ser construídos, apenas, sobre o valor intrínseco das capacitações pessoais e não pela disponibilidade econômica às participações. Não é utopia, mas projeto (para nossos netos) e o primeiro passo é o de não cobrar de quem ensina.

Claro que há muitos dispostos a pagar por esse exercício: a (suposta) detenção do saber e a (presumível) capacidade de informar é geradora de prestígio, meio de promoção pessoal e, consequentemente, possível causa de referências, portanto recursos. Pelos caminhos desse raciocínio, chegar-se-á à conclusão de que tal "professor" já está então recebendo seu pagamento: tudo uma questão de mais (ou menos) valia. Daí, porém, o meu viés, assumido, de acadêmico, de profissional do ensino, de professor sem aspas: tal atitude, ainda que encontradiça, não pode trazer perclusão ao princípio maior, o de que a aula "em si" independe dessa "mais valia"; ou, por outras palavras, de que tal pagamento pode atender aos interesses do médico que profere a aula, mas não, necessariamente, ao do professor que ensina Medicina. Daí, também, o meu aplauso (e de muitos outros), incondicional, ao belíssimo passo à frente dado neste XXXI Congresso Brasileiro de Oftalmologia no qual, pela primeira vez, reconheceu-se oficialmente (e já era tempo) a função magisterial, deixando-se de cobrar a inscrição ao conferencista, ao simposiasta, ou professor de curso. Parabéns aos Presidentes Newton Kara José e Rubens Belfort Júnior e às Comissões Organizadoras. Tomara que o exemplo frutifique!

Diferente é o conceito de cobrança de anuidade (participação) de uma Sociedade e a exigibilidade de que só estejam em seus programas os membros dela. Dessa forma, uma associação pode se fechar em função de um patamar econômico, excluído dela (e de suas reuniões) quaisquer menos abonados, ainda que não cobre inscrições de conferencistas ou, até, dos ouvintes... (a anuidade fica como pagamento camuflado de participação nos eventos). Mas aceitandose a liberdade de associações e dando-se fé ao argumento cooperativista em suas constituições (portanto, num grupo de iguais, todos devem contribuir) não há o que reclamar. A não ser quanto ao fato de que se trate de uma sociedade exclusivista, deixando de aplicar como argumento seletivo a valoração do conhecimento.

A carta de Renato Curi avança, ainda, por uma colateral. Chama a atenção a que o aproveitamento da "mais valia" da informação, ou da experiência, no conteúdo da aula ministrada e até na própria forma de fazê-lo (as artes gráficas e os recursos de exposição) já transcende à responsabilidade do Congresso e passa a entidades privadas: a gravação de vídeos e suas comercializações. Aqui, entretanto, a decisão cabe ao próprio interessado, autorizando, ou não, o procedimento de registro de suas imagens e palavras, para entregar, graciosamente, o direito sobre elas. Faz assim quem quer, mas a carta de advertência remete a reflexões sobre o assunto e à formação de opiniões. E nem chego a acreditar que estariam cobrando, dos professores, as fitas com suas aulas. Aí, também, já é demais...

Enfim, parece hora de tomada de consciências: dos professores quanto aos seus valores e direitos (e deveres); dos organizadores de eventos sobre suas finalidades e deveres (e direitos). 